\title{
KEDUDUKAN DAN FUNGSI DEWAN PERWAKILAN DAERAH (DPD) DALAM SISTEM KETATANEGARAAN INDONESIA
}

\section{Parlindungan Pasaribu}

\author{
Dosen Fakultas Hukum Universitas Widya Gama Mahakam Samarinda
}

\begin{abstract}
ABSTRAK
Dewan Perwakilan Daerah (DPD) merupakan unsur utusan daerah dan merupakan anggota Majelis Permusyawaratan Rakyat (MPR), yang diatur dalam Undang-Undang Dasar 1945 Pasal 1 ayat (2), Pasal 22C dan Pasal 22D, setelah mengalami perubahan. Adapun gagasan semula dibentuknya Dewan Perwakilan Daerah adalah untuk menggantikan sistem perwakilan satu kamar menjadi dua kamar, namun dalam perjalanannya tidak diberikan kewenangan yang mamadai untuk menjalankan funngsi lembaga perwakilan daerah.

Kedudukan dan fungsi Dewan Perwakilan Daerah diharapkan dapat secara optimal memperjuangkan aspirasi daerah-daerah, tetapi ternyata Undang-Undang tidak memberikan kewenangan yang mamadai kepada Dewan Perwakilan Daerah untuk mempresentasikan kepentingan daerah, yaitu fuingsi legislasi, pengawasan maupun anggaran tidak diberikan sepenuhnya, karena DPD hanya dapat mengajukan rancangan Undang-Undang yang kemudian diserahkan kepada DPR, begitu juga tentang anggaran harus menyampaikan kepada DPR agar ditindak lanjuti, sehingga DPD tidak berwenang untuk membahasnya, walaupun juga dapat menjalin hubungan dengan lembaga negara lainnya tetapi tidak seperti DPR, oleh karena itu dapat dikatakan bahwa keberadaan DPD tidak merupakan salah satu kamar dalam lembaga perwakilan yang dapat memperjuangkan aspirasi rakyat, tetapi merupakan lembaga yang berdiri sendiri, dan mempunyai fungsi berbeda dengan DPR.
\end{abstract}

Kata Kunci : Kedudukan dan Fungsi DPD.

\section{PENDAHULUAN}

Indonesia adalah negara demokrasi, pernyataan itu secara tegas termuat dalam Pasal 1 ayat (2) Undang-Undang Dasar 1945 yang berbunyi :'Kedaulatan berada di tangan rakyat dan dilaksanakan menurut Undang-Undang Dasar." Kemudian Pasal 2 ayat (1) Undang-Undang Dasar 1945 menyebutkan bahwa : " Mejelis Permusyawaratan Rakyat terdiri atas anggota Dewan Perwakilan Rakyat (DPR) dan anggota Dewan Perwakilan Daerah (DPD) yang dipilih melalui pemilihan umum dan diatur lebih lanjut dengan Undang-Undang." Dengan demikian di Indonesia kekuasaan tertinggi berada pada rakyat, demikian di sebuah negara yang menamakan dirinya sebagai negara demokrasi, tetapi dalam menjalankan kedaulatan dimaksud harus rakyat memilih wakil-wakilnya yang duduk dalam Mejelis Permusyawaratan Rakyat (MPR) untuk menjalankan tugas sesuai dengan fungsinya, berdasarkan UndangUndang Dasar. 
Anggota MPR merupakan derivasi anggota DPR dan DPD; Keduanya dipilih oleh rakyat secara langsung dari daerah tertentu, bedanya bahwa anggota DPR dipilih melalui pemilihan umum dengan jumlah penduduk tertentu yang diwakili melalui partai politik, sedangkan anggota DPD dipilih melalui pemilihan umum mewakili masyarakat pada wilayah tertentu tidak melalui partai politik, keduanya merupakan jembatan bagi aspirasi daerah dalam pembuatan kebijakan nasional, dalam rangka mekanisme check and balances. Dewan Perwakilan Rakyat (DPR) dimaksudkan untuk mewakili rakyat, sedangkan Dewan Perwakilan Daerah dimaksudkan untuk mewakili daerah, maksudnya adalah kepentingan yang harus lebih diutamakan dalam rangka perwakilan daerah, adalah kepentingan daerah secara keseluruhan, terlepas dari kepentingan individu-individu yang kepentingannya sudah disalurkan melalui DPR. Hal ini penting untuk diketahui agar dapat membedakan keterwakilan ganda dengan mengartikan fungsi parleman yang dijalankan oleh DPR dan DPD.

Menurut Bagir Manan (2003), pada awalnya ada berbagai gagasan dibalik kelahiran Dewan Perwakilan Daerah (DPD, yaitu :

Pertama : gagasan mengubah sistem perwakilan menjadi sistem dua kamar (bicameral), DPD dan DPR digambarkan serupa dengan sistem perwakilan seperti di Amerika Serikat yang terdiri dari Senate sebagai perwakilan negara bagian (DPD), dan House of Representatives sebagai perwakilan seluruh rakyat (DPR). Di Amerika Serikat kedua unsur perwakilan tersebut dinamakan Konggres (Congress). Pasal 1 ayat (1) UUD Amerika Serikat (1787) menyebutkan :"All legislative power herein granted in a Congress of a United States, which shall consist of Senate and House of Representatives." (seluruh kekuasaan perundang-undangan yang ada berdasarkan konstitusi ini dikatakan pada sebuah konggres yang terdiri dari Senat dan Dewan Perwakilan Daerah).

Kedua : gagasan untuk meningkatkan keikutsertaan daerah terhadap jalannya politik dan pengelolaan negara. DPD merupakan badan sehari-hari yang turut serta menentukan dan mengawasi jalannya politik dan pengelolaan negara. Dengan demikian, dapat pula dipandang sebagai koreksi atau penyempurnaan sistem utusan daerah di MPR menurut Pasal 2 ayat (1) Undang-Undang Dasar 1945 sebelum perubahan. (Bagir Manan, 2003, hal : 53-54).

Antara DPR dan DPD mempunyai kewenangan yang berbeda, jika DPR mempunyai fungsi legislasi, anggaran dan pengawasan, tetapi DPD tidak mempunyai fungsi legislasi, anggaran dan pengwasan seperti yang dimliki oleh DPR. Kewenangan yang sangat terbatas yang dimiliki oleh DPD berdampak pada pelaksanaan fungsi DPD sebagai badan perwakilan daerah dipandang tidak memilki fungsi selayaknya badan perwakilan rakyat yakni fungsi legilasi, fungsi anggaran dan fungsi pengawasan, karena pada kenyataannya DPD tidak memegang kekuasaan membentuk UndangUndang, hanya dapat mengajukan rancangan Undang-Undang kepada DPR, sehingga DPD seperti biro perencanaan Undang-Undang DPR. Hal itu juga disebabkan karena DPD tidak berhak untuk membahas Rancangan Undang-Undang menjadi UndangUndang, karena yang dapat membahas adalah DPR dan Presiden untuk mendapat persetujuan bersama. Ketentuan tersebut merupakan bukti bahwa terjadi amputasi terhadap DPD, sehingga didapati substansi yang anomaly bila dilihat dari kedudukan dan fungsinya sebagai badan perwakilan rakyat. 
Dalam hal anggaran, DPD juga tidak mempunyai kekuasaan untuk membahasnya serta tidak mempunyai hak inisiatif dan mandiri dalam bentuk Undang-Undang lain, DPD sama sekali tidak memiliki original power dalam pembentukan sebuah UndangUndang atau kekuasaan legislatif lainnya, tentu saja hal ini berbeda dengan House of Representatives dan Senate di Amerika Serikat. Kemudian mengenai fungsi pengawasan, bahwa DPD tidak bersifat imperatif, karena di dalam Undang-Undang terdapat kata-kata "dapat", berarti bukan merupakan kewajiban, dan disamping itu dari hasil pengawasan yang dilakukan oleh DPD tidak mengikat untuk ditindak lanjuti oleh DPR, karena hasil pengawasan yang dilakukan oleh DPD harus disampikan kepada DPR, dan DPR lah yang menentukan untuk dilakukan atau tidaknya hasil pengawasan DPD tersebut, maka diri itu dapat dikatakan pengawasan yang dilakukan oleh DPD berdampak sia-sia, jika pada akhirnya DPR tidak mau menindaklanjutinya.

Undang-Undang Dasar 1945 memberikan kewenangan kepada DPD yang bersifat terbatas, tentu hal ini dapat dipandang sebagai tidak mencerminkan mengikut sertakan daerah dalam menyelenggarakan jalannya politik dan pengelolaan negara juga merupakan sesuatu hal yang ganjil jika ditinjau dari konsep dua kamar, karena gagasan badan perwakilan daerah sebagai unsur badan legislatif seperti di Amerika serikat dimaksudkan sebagai cara untuk mengikut sertakan daerah dalam menetukan politik dan pengelolaan negara melalui pembentukan Undang-Undang di lembaga legislatif, maupun pengawasan jalannya pemerintahan, dan bukan saja hanya sekedar persoalanpersoalan daerah, terlebih mengenai anggaran yang notabene sudah menjadi kewenangan DPR saja dalam membahas maupun menganggarkannya.

Jika diperhatikan ketentuan-ketentuan dalam Undang-Undang Dasar 1945 setelah mengalami perubahan tidak nampak gagasan sistem dua kamar. Pada Undang-Undang Dasar 1945 sebelum peruibahan hanya terdapat dua badan perwakilan pusat yang terpisah, yaitu DPR dan MPR, tetapi setelah mengalami perubahan sampai yang keempat kalinya menjadi tiga badan perwakilan, yaitu MPR, DPR dan DPD, alasannya adalah :

Pertama : Walaupun ada perubahan, MPR merupakan lingkungan jabatan sendiri, MPR memilki wewenang sendiri (original) diluar wewenang DPR dan DPD.

Kedua : Sepintas lalu DPD merupakan lingkungan jabatan mandiri dan memilki wewenang sendiri.

Ketiga : DPD bukan badan legislatif penuh, artinya DPD hanya berwenang mengajukan dan membahas Rancangan Undang-Undang dalam bidang tertantu saja yang disebut secara enumerative dalam UUD 1945. Terdapat hal-hal lain dan kewenangan pembentukan Undang-Undang hanya ada pada DPR dan Pemerintah. (Ni'Matul Huda, 2003, hal : 263-263).

Menurut Jimly Assiddiqie (2004), Perubahan Undang-Ungang Dasar 1945 lebih mengadopsi gagasan parlemen bicameral yang bersifat soft, karena kedua kamar dewan perwakilan rakyat tersebut tidak dilengkapi dengan kewenangan yang sama kuat, Yang lebih kuat tetap Dewan Perwakilan Rakyat, sedangkan Dewan Perwakilan Daerah hanya bersifat tambahan dan terbatas pada hal-hal yang berkaitan dengan kepentingan daerah. (Jimly Asshiddiqie, 2004, hal : 25). Dengan kewenangan yang demikian maka dapat dipahami bahwa dominasi legislatif masih tetap ada pada DPR, sedangkan utusan daerah hanya sebagai simbul dalam rangka mengganti utusan daerah 
yang lama, hanya bedanya utusan daerah yang baru dipilih oleh rakyat secara langsung berdasarkan wilayah pemilihan.

Di samping itu, dengan adanya kewenangan yang demikian, maka dapat dipahami bahwa MPR itu merupakan lembaga yang berdiri sendiri disamping DPR dan DPD, dengan demikian Undang-Undang Dasar 1945 dipandang memperkenalkan sistem parlemen tricameral atau tricameralisme. Dan menurut Ni'matul Huda (2003), dalam sistem tiga kamar (tricameral) struktur organisasi parlemen nasional terdiri atas tiga badan masing-masing mempunyai fungsi sendiri-sendiri. (Ni'matul Huda, 2003, hal : 238).

Keberadaan Undang-Undang yang mengtur tentang Susunan dan Kedudukan Majelis Permusyawaratan Rakyat (MPR), Dewan Perwakilan Rakyat (DPR, dan Dewan Perwakilan Daerah (DPD) telah semakin menegaskan bahwa sistem bicameral, sebagaimana gagasan yang melandasi perubahan kelembagaan MPR, tetapi menganut sistem tricameral, karena MPR, DPR dan DPD merupakan lembaga yang masingmasing memiliki jabatan, tugas dan wewenang sendiri-sendiri, disamping itu UndangUndang juga menegaskan bahwa DPD memiliki wewenang dan fungsi yang terbatas dan tidak sebagaimana mestinya fungsi lembaga perwakilan, yang mewakili daerahdaerah di seluruh Indonesia, agar dapat memperjuangkan kepentingan daerah, inilah suatu hal yang menjadi problem dalam sistem ketatanegaraan Republik Indonesia.

Walaupun keberadaan DPD sebenarnya relatif baru, dan lahir pada era reformasi, tetapi kenyataannya memang demikian, hal ini tidak dapat dipungkiri bahwa situasi politik hukum yang sangat berperan dalam menentukan segala perundang-undangan di suatu negara, namun demikian jika dibandingkan dengan sistem ketatanegaraan pada era orde baru, dimana utusan daerah hanya ditunjuk berdasarkan kekuasaan kepala daerah saja, tentu hal itu mencerminkan kurang demokrasi, sedangkan utusan daerah yang sekarang disebut DPD sudah tidak ditunjuk langsung oleh kepala daerah, tetapi sudah melalui mekanisme yang demokrasi yaitu melalui pemilihan umum secara langsung, walaupun DPD tidak mewakili partai politik tertentu, hal ini menunjukkan bahwa lambat laun sisten politik demokrasi di Indonesia semakin dewasa dan semakin baik, maka kajian ini marupakan salah satu kajian yang menarik untuk dilakukan penelitian secara normatif, agar didapat diskripsi dan jawaban atas permasalahan yang dikemukan.

Berdasarkan uraian diatas penulis tertarik untuk melakukan penelitian secara normatif terhadap masalah-masalah yang menyangkut tugas dan fungsi Dewan Perwakilan Daerah (DPD), dan hasilnya dituangkan dalam sebuah jurnal ilmiah agar dapat dibaca oleh para pembaca yang budiman. Karena pentingnya masalah ini maka penulis menuangkannya dalam laporan hasil penelitian ini dengan judul : "Kedudukan dan Fungsi Dewan Perwakilan Daerah (DPD) Dalam sistem Ketetanegaraan Indonesia."

\section{RUMUSAN MASALAH}

Berdasarkan uraian yang termuat pada pendahuluan atau latar belakang, maka dapat dirumuskan masalah penelitian ini sebagai berikut :

1. Bagaimana kedudukan dan fungsi DPD dalam sistem ketatanegaraan Indonesia? 
2. Bagaimana hubungan DPD dengan lembaga-lembaga negara lainnya?

\section{TUJUAN PENELITIAN}

Sesuai dengan rumusan masalah yang ada, maka penelitian ini bertujuan untuk menemukan konsep yang tetap mengenai kedudukan dan fungsi Dewan Perwakilan Daerah (DPD), dalam sistem ketatanegaraan Indonesia. Atas dasar konsep tersebut, maka tujuan penelitian ini adalah :

1. Untuk mengetahui bagaimana kedudukan dan fungsi DPD dalam sistem ketatanegaraan Indonesia.

2. Untuk mengetahui bagaimana hubungan DPD dengan lembaga negara lainnya ?

\section{METODE PENELITIAN}

Dalam penelitian ini yang menjadi sentral kajiannya adalah kedudukan dan fungsi Dewan Perwakilan Daerah (DPD), yang merupakan bagian dari hukum administrasi negara, maka tipe penelitiannya adalah penelitian hukum, yaitu sebagai penelitian untuk menemukan hukum in concreto, yang meliputi berbagai kegiatan untuk menemukan apakah yang merupakan hukum yang layak untuk diterapkan secara in concreto untuk menyelesaikan suatu yang didasarkan pada metode, sistematika dan pemikiran tertentu, dengan jalan menganilsisnya. (Soerjono Soekanto, 2005, hal : 43).

Dilihat dari tipologi penelitian mengenai kedudukan dan fungsi Dewan Perwakilan Daerah dalam sistem ketatanegaraan Indonesia ini digolongkan dalam jenis penelitian hukum normatif, yang hanya menelaah data sekunder, (Abdulkadir Muhammad, 2004, hal : 52), dan jika dilihat dari tujuannya maka penelitian hukum normatif menggunakan metode doktrinal normologi, yaitu bertolak dari kaidah-kaidah sebagai ajaran yang mengkaidahi perilaku. (Bernard Arif Sidharta, 1996, hal : 190).

Dengan demikian penelitian hukum normatif ini mengkaji hukum yang dikonsepkan sebagai norma atau kaidah yang berlaku dalam masyarakat dan menjadi acuan perilaku setiap orang, adapun norma hukum yang berlaku itu adalah norma hukum positif tertulis yang dibentuk oleh lembaga negara barupa Undang-Undang Dasar, Undang-Undang, kodifikasi, Peraturan-Peraturan Pemerintah, oleh karenanya penelitian hukum normatif ini tidak mengkaji pelaksanaan atau implementasi hukum. Sedangkan penulisannya bersifat diskriptif analisis, yaitu berusaha memberikan gambaran atau uraian mengenai masalah-masalah yang dirumuskan dalam rumusan masalahnya.

\section{LANDASAN TEORI}

Dalam penelitian ini yang menjadi konsep kajian utama adalah demokrasi sebagai teori utama (grend teory), kemudian juga akan digunakan teori-teori tentang lembaga perwakilan. Berdasarkan kamus hukum, demokrasi (democratie) adalah bentuk pemerintahan atau kekuasaan negara yang tertinggi, dimana sumber kekuasaan negara 
yang tertinggi adalah kekuasaan (ke) rakyat (an) yang terhimpun melalui suatu majelis yang dinamakan Majelis Permusywarat Rakyat (die gasamte staatgeweltleigt ollen bet der majelis). (Yan Pramudya Puspa, 1977, hal : 295). Selain itu kamus Dictionary webters mendefinisikan demokrasi adalah pemerintah oleh rakyat dimana kekuasaan tertinggi berada ditangan rakyat dan dijlankan langsung oleh mereka atau oleh wakilwakil yang mereka pilih di bawah sistem pemilihan umum bebas.(Sabirin Malian, 2001, hal : 44)

Dari pengertian tersebut, maka konsep demokrasi berakar dari konsep kedaulatan rakyat. Menurut ajaran kedaulatan rakyat, kekuasaan tertinggi ada pada rakyat, artinya bahwa pada tingkat terakhir rakyatlah yang memberi keputusan dalam masalah pokok mengenai kehidupannya, termasuk dalam menilai kebijakan pemerintah dan negara. Dalam perspektif demikian, negara ada karena kemauan bersama dari rakyatnya. Selama negara itu ada, maka segala tindakan dengan caranya bertindak harus sesuai dengan kemauan bersama dari rakyatnya, oleh karena itu organisasi dan perjalanan negara seharusnya ditetapkan oleh kemauan bersama.(M.Nasroen, 1986, hal : 66).

Dalam negara demokrasi, rakyat merupakan sumber kekuasaan, artinya dalam proses bernegara, raklyat sering dianggap sebagai hulu dan sekaligus muaranya, rakyat merupakan titik sentral dan pemegang kedaulatan atau benar-benar berdaulat.(I Gede Panca Astawa, 2000, hal : 30). Hal ini berarti bahwa kedaulatan bersifat kerakyatan dan didasarkan kepada kemauan umum. (Jimly Asshiddiqie, 1995, hal 14). Hubungan antara rakyat dan kekuasaan dalam negara demokrasi lazimnya dikembangkan atas dasar dua teori, yaitu teori demokrasi langsung (direct democracy), dimana kedaulatan rakyat dapat dilakukan secara langsung dalam arti rakyat sendirilah yang melaksanakan kekuasaan tertinggi yang dimilikinya, dan teori demokrasi tidak langsung (Representative democracy) atau demokrasi perwakilan. ( Jimly Asshiddiqie, 1994, hal : 70).

Dengan berkembangnya gagasan bahwa kedaulatan berada di tangan rakyat, maka Dewan Perwakilan Rakyat menjadi badan yang berhak menyelenggarakan kedaulatan itu dengan jalan menentukan kebijaksanaan umum dan menuangkannya dalam bentuk Undang-Undang. Oleh karena itu Dewan Perwakilan Rakyat sering disebut badan legislatif yang diartikan sebagai lembaga yang "legislate" atau pembuat Undang-Undang. Lalu bagaimana dengan Dewan Perwakilan Daerah (DPD) yang juga merupkan bagian dari MPR, adalah sebuah lembaga negara yang dipilih oleh rakyat secara langsung dan mewakili wilayah atau daerah diseluruh Indonesia, apakah juga dapat dikatakan lembaga yang "legislate" seperti DPR. Tentu jawabannya tidak bisa disamakan, karena tergantung dari bagaimana Undang-Undang Dasarnya mengatur tentang hal itu, sedangkan di Indonesia Undang-Undang Dasar 1945 mengatur berbeda kewenangan yang dimilikki oleh DPR dan DPD.

Kemudian mengenai Lembaga Perwakilan. Bahwa perwakilan (representation) adalah konsep seseorang atau suatu kelompok mempunyai kemampuan atau kewajiban untuk bicara dan bertindak atas nama suatu kelompok yang lebih besar. Dewasa ini pada umumnya mewakili rakyat melalui partai politik. Hal ini dinamakan perwakilan yang bersifat politik (political representation). Sekalipun asas perwakilan politik telah menjadi sangat umum, akan tetapi ada beberapa kalangan yang merasa bahwa politik dan perwakilan yang berdasarkan kesatuan-kesatuan politik semata, telah mengabaikan kepentingan-kepentingan dan kekuatan-kekuatan lain yang ada di dalam masyarakat. Beberapa negara telah mencoba untuk mengatasi persoalan ini dengan 
mengikutsertakan wakil dari golongan-golongan yang memerlukan perlindungan khusus.(Mirian Budiarjo, 1982, hal : 175)

Berdasarkan susunannya badan perwakilan rakyat dapat dibedakan atas perwakilan bicameral dan perwakilan unicameral. Bicameral berarti terdiri dari dua kamar atau dua dewan atau dua balai, sedangkan unicameral berarti terdiri dari satu kamar atau satu dewan. (M. Solly Lubis, 2002, hal : 70). Di dalam praktek dewasa ini ada negara dimana bedan legislatif terbagi dalam dua majelis ( bicameralisme) dan satu majelis (unicameralisme). Boleh dikatakan bahwa semua negara federal memakai sistem dua mejelis, oleh karena itu di antaranya mewakili kepentingan negara bagiannya khususnya (India, Amerika Serikat). (Miriam Budiadrjo, op.cit, hal : 180).

Di Indonesia setelah terjadi reformasi timbul gagasan baru untuk membentuk lembaga perwakilan dengan sistem dua kamar (biucameral), hal tersebut dalam rangka mengikut sertakan daerah terhadap jalannya politik dan pengelolaan negara, maka terjadilah perubahan Undang-Undang Dasar 1945 yang merubah utusan daerah dalam keaggotaan MPR dihapus dan diganti dengan sebuah lembaga baru yaitu Dewan Perwakilan Daerah (DPD), adalah merupakan badan sehari-hari yang turut serta menentukan dan mengawasi jalannya politik dan pengelolaan negara. Sebelumnya keikut sertaan utusan daerah yang ada pada MPR sebelum perubahan Undang-Undang Dasar 1945 sangat terbatas yaitu mengikuti sidang MPR yang dilaksanakan dua kali selama lima tahun, yakni sidang masa awal dan akhir masa jabatan Presiden. Kemudian setelah mengalami perubahan walaupun tetap menggunakan nama MPR, tetapi wewenang MPR tidak otomotis melekat pada wewenang DPR dan DPD, melainkan memiliki wewenang sendiri.

Berdasarkan formasi bahwa MPR mempunyai kewenangan sendiri, maka sebenarnya di Indonesia terdapat tiga badan, yaitu MPR, DPR dan DPD, maka formulasi ini sulit dimengerti karena tidak ada dasar teori yang memungkinkan dibentuknya lembaga perwakilan seperti itu. Namun demikian telah terjadi pergeseran yang cukup besar, yakni kekuasaan MPR menjadi berkurang, yakni tidak lagi dapat menetapkan produk hukum seperti Tap MPR, namun kewenangan MPR hanyalah menetapkan dan mengubah Undang-Undang dasar dan melantik Presiden, kemudian dalam hal tertentu MPR dapan memilih Presiden dan/atau wakil Presiden. Sebaliknya kekuasaan DPR menjadi lebih besar, karena fungsi pembentukan Undang-Undang dialihkan dari Ptresiden kepada DPR, sedangkan Presiden hanya diberi hak untuk mengajukan rancangan saja.

Selain itu DPR diberi kekuasaan untuk menyetujui dan mempertimbangkan beberapa kekuasaan yang dijalankan oleh ekskutif, seperti mengangkat duta besar, memberi amnesty, mengakat Panglima TNI, mengangkat Kepala Kepolisian Negara dan sebagainya. Selain DPR ada lembaga perwakilan yang baru yakni Dewan Perwakialan Daerah (DPD) yang juga dipilih secara langsung oleh rakyat untuk mewakili daerah dalam wilayah tertentu, namun demikian tugas dan wewenangnya tidak sama dengan DPR, dan bahkan tidak mempunyai kewenangan sama sekali dalam hal menentukan kebijakan-kebijakan, artinya tidak ikut politik dalam pengelolaan negara seperti halnya DPR yang kewenangannya begitu basar.

Menurut M. Solly Lubis (2002), yang menjadi dasar bagi perwakilan yang ada di dunia, antara lain : dasar kedudukan sosial yang terdapat dalam masyarakat, misalnya golongan agama, cendikiawan, buruh, tani, seniman dan sebagainya; Dasar geografi, 
yaitu adanya kepentingan daerah-daerah tertentu yang harus diwakili oleh wakil-wakil tertentu di forum perwakilan, dan dasar kepentingan, yaitu kepentingan-kepentingan yang disalurkan melalui partai politik. (M. Solly Lubis, 2002, hal : 76). Sehubungan badan perwakilan merupakan organisasi yang mengorganisir wakil-wakil rakyat yang mengambil peran yang mesti dijalankan oleh badan perwakilan itu, maka problem keterwakilan dalam badan perwakilan dapat ditemukan terutama yang berkenaan dengan hubungan antara wakil rakyat dengan yang diwakilinya. Dalam konteks ini, beberapa teori mencoba memberikan jawabannya, yaitu teori mandate dan teori organ. (Bintan R Saragih, 1988, hal : 81).

\section{PEMBAHASAN}

\section{A. Kedudukan dan Fungsi DPD}

Perubahan Undang-Undang Dasar 1945 membawa implikasi yang sangat luas terhadap sistem ketatanegaraan Republik Indonesai, terutama mengenai kelembagaan negara, yang mendapat tambahan kewenangan, ada yang dikurangi kewenangannya, ada pula lembaga negara yang dihapus sama sekali, dan ditambah beberapa lembaga negara yang baru. Khusus mengenai lembaga perwakilan, terdapat perubahan, yakni dengan mengurangi kewenagnan MPR dan mengubah kedudukannya dari lembaga tinggi negara menjadi lembaga negara, sedangkan untuk DPR kewenangannya menjadi lebih luas, karena diberi hak untuk ikut campur tangan dalam hal pengambilan keputusan oleh Presiden, yaitu dengan meminta persetujuan dan pertimbangan.

Selain kedua lembaga perwakilan tersebut, melalui perubahan Ungang-Undang Dasar 1945juga ditambah satu lembaga negara yang baru, yakni Dewan Perwakilan Daerrah (DPD), sebagai lembaga perwakilan tingkat pusat yang mewakili daerah. Adapun latar belakang terbentuknya DPD melalui perubahan Undang-Undang Dasar 1945 adalah untuk mengganti peran anggota MPR dari unsur Utusan Daerah, yang sebelumnya menjadi salah satu unsur dalam anggota MPR yang diangkat; Disamping itu juga bahwa DPD diadakan dalam rangka mewujudkan gagasan utnuk membentuk lembaga perwakilan dengan sistem dua kamar (bicameral). Namun apabila dilihat dari segi kewenangan yang diberikan kepadanya, maka maksud tersebut belum dapat diwujudkan spenuhnya, karena werwenang yang diberikan kepada DPD sangat terbatas dalam pembentukan Undang-Undang, bahkan sebagian kalangan berpendapat bahwa DPD hanya sebagai pelengkap atau sub ordinasi dari DPR.

Mengacu pada uraian diatas, maka dapat dikatakan bahwa sistem perwakilan yang dianut oleh Undang-Undang dasar 1945 setelah mengalami perubahan menjadi tidak jelas, karena bukan menganut sistem satu kamar, bukan pula sistem dua kamar, tetapi ada yang berpendapat bahwa UUD 1945 setelah perubahan menganut sistem tiga kamar, yakni MPR, DPR dan DPD yang masing-masing mempunyai kewenangan sendiri yang berbeda diantara ketiganya, namun secara teoritis maupun faktual ataupun yuridis tidak dikenal adanya lembaga perwakilan dengan sistem tiga kamar. Argumentasi mengenai sistem perwakilan di Indonesia setelah perubahan UndangUndang dasar 1945 tidak jelas, dapat dikemukakan hal-hal sebagai berikut :

1. Bahwa MPR memiliki kewenangan yang berdiri sendiri diluar wewenang DPR dan DPD. 
2. Bahwa DPD hanya merupakan lembaga komplementer dari DPR, didasarkan atas ketentuan-ketentuan sebagai berikut : DPD dapat mengajukan kepada DPR rancangan Undang-Undang. DPD menyampaikan hasil pengawasannya kepada DPR sebagai bahan pertimbangan untuk ditindak lanjuti.

3. DPD bukan merupakan badan legislatif penuh, karena hanya memiliki wewenang pembentukan Undang-Undang dibidang btertentu saja yang disebut secara tegas dalam UUD1945.

Dewan Perwakilan Daerah (DPD) merupakan lembaga perwakilan daerah yang berkedudukan sebagai lembaga negara setingkat dengan kedudukan lembaga negara lainnya, hanya kewenangannya yang berbeda. Istilah kedudukan menunjukkan pada setatus yaitu keadaan tingkatan organ, badan atau negara. Dalam hal, ini berarti bahwa DPD sebagai lembaga perwakilan mempunyai tingkatan yang sama dengan lembaga negara yang lainnya. Kedudukan diartikan sebagai posisi suatu lembaga negara dibandingkan dengan lembaga negara lain, sedangkan posisi yang dimaksud adalah didasarkan pada fungsi utamanya. Maka dari pengertian ini berdasarkan UUD 1945 setelah mengalami perubahan, tidak lagi dikenal adanya lembaga tertinggi negara dan lembaga tinggi negara, malainkan dikenal hanya lembaga negara, hal ini berarti bahwa semua lembaga negara mempunyai kedudukan yang sama, hanya perbedaannya terletak pada fungsi masing-masing; Dengan demikian kedudukan DPD sama dengan MPR, DPR, BPK, Presiden, MA dan MK.

Menganai fungsi Dewan Perwakilan Daerah terbatas, terutama tentang substansinya, baik mengenai usul rancangan Undang-Undang maupun pengawasan atas pelaksanaan Undang-Undang itu sendiri, jika dirinci mengenai fungsi DPD ada empat hal, yaitu :

1. Mengajukan ususl rancangan Undang-Undang;

2. Ikut dalam pembahasan;

3. Ikut mempertimbangkan; dan

4. Pengawasan atas pelaksanaan Undang-UIndang.

Fungsi pengajuan usul dan ikut dalam pembahasan RUU hanya dibatasi pada substansi pengaturan tertentu saja, sedangkan materi yang dimaksud adalah hanya terbatas pada materi Rancangan Undang-Undang yang berkaitan dengan otonomi daerah, hubungan pusat dan daerah, pembentukan dan pemekaran serta penggabungan daerah, pengelolaan sumber daya alam dan sumber daya ekonomi lainnya, dan perimbangan keuangan antara pusat dan daerah, sedangkan keikutsertaan DPD dalam pertimbangan, hanya dibatasi pada RUU tentang APBN, pajak, pendidikan, Agama, yang mana RUU ini bukan merupakan usul dari DPD. Dengan demikian dapat disimpulkan bahwa DPD tidak mempunyai fungsi sebagaimana yang dimiliki oleh DPR, yaitu fungsi legislatif, anggaran dan pengawasa, sehingga fungsi DPD tidak sama dengan fungsi DPR.

\section{B. Hubungan DPD Dengan Lembaga Negara Lainnya}

Secara umum hubungan antara alat perlengkapan negara (lembaga negara) dapat dibedakan atas dua hal, yaitu hubungan secara vertikal dan hubungan secara horisotal. Hubungan secara vertikal adalah berkaitan dengan kedudukan wilayah-wilayah dalam 
negara. Apakah bagian-bagian ini berkedudukan sebagai negara atau sebagai daerah dalam suatu ikatan negara. Jika bagian itu bersetatus negara, maka negara itu susunannya sebagai negara serikat, dan apabila bersetatus daerah, maka negara itu bersusunan negara kesatuan. Sedangkan hubungan horisontal adalah hubungan antar alat perlengkapan alat negara (lembaga negara) di tingkat pusat sebagai akibat adanya teori trias politica yang menghendaki adanya pemisahan atau pembagian kekuasaan di dalam negara. Dengan demikian dimensi dari hubungan ini tidak lain adalah hubungan antar pemegang kekuasaan legislatif, ekskutif dan yudikatif.

Hubungan DPD dengan MPR adalah bahwa anggota DPD juga sekaligus merupakan anggota MPR, yang menjalankan tugas dan fungsi dalam kedua lembaga secara terpisah pada waktu yang berbeda; Para anggota DPD ketika melaksanakan tugas dan fungsi MPR tidak mewakili DPD, melainkan sebagai pribadi seorang anggota MPR, begitu juga sebaliknya, ketika melaksanakan tugas sebagai DPD tidak secara otomatis mewakili MPR, karena kedua lembaga tersebut mempunyai tugas dan fungsi yang berbeda. Hubungan ini berbeda dengan sistem bicameral, yakni ketika melaksanakan tugas dan fungsi MPR, para anggota MPR itu tetap berkedudukan sebagai anggota DPD, hal ini berarti bahwa perubahan Undang-Undang Dasar 1945 tidak membawa konskwensi ketatanegaraan Indonesia, khusunya mengenai anggota MPR yang berasal dari utusan daerah.

Hubungan DPD dengan DPR semula digagas sebagai dua kamar yang berbeda dalam satu lembaga legislatif. Namun ternyata kedua lembaga tersebut merupakan lembaga yang mandiri dengan kekuasaan masing-masing. Antara keduanya mempunyai hubungan kekuasaan yang terwujud dalam fungsi legislatif dan fungsi pengawasan. DPD hanya diberi kewenangan untuk mengajukan RUU dalam bidang tertentu, serta ikut pembahasan dengan DPR sebelum dibahas antara DPR dengan Presiden, DPD tidak diberi kewenangan untuk membahas RUU lebih lanjut. Begitu juga mengenai pengawasan, DPD menyerahkan hasil pengawasan kepada DPR untuk ditindak lanjuti, jadi DPD tidak mempunyai fungsi pengawasan secara mandiri, semua yang dilakukan harus disampaikan kepada DPR.

Hubungan DPD dengan Presiden terkait dengan dua posisi DPD, yakni sebagai anggota DPD di satu sisi dan sebagai anggota MPR disisi lain. Jika sebagai anggota DPD hubungannya hanya menyampaikan RUU kepada DPR kemudian DPR membahasnya bersama-sama dengan Presiden, maka hubungan DPD dengan Presiden merupakan hubungan yang tidak langsung, karena harus melalui DPR sebagai perantara terkait dengan pengajuan RUU, maupun hasil pengawasan yang telah di lakukan. Kemudian posisinya sebagai anggota MPR adalah hanya melantik Presiden dan/atau wakil Presiden, serta dapat memberhentikan Presiden dan/atau wakil Presiden dalam masa jabatannya menurut Undang-Undang Dasar, bila dimungkinkan.

Hubungan antara DPD dengan BPK, bahwa hasil pemeriksaan BPK diserahkan kepada DPR, DPD dan DPRD sesuai dengan kewenangannya masing-masing, kemudian hubungan yang lain nampak dalam hal pengisian keanggotaan BPK, maka DPD diberi hak untuk memberikan pertimbangan kepada DPR, kemudian DPR memutus sendiri dan dapat menggunakan atau tidak menggunakan pertimbamngan dari DPD; Dengan demikian substansi huibungan DPD dengan BPK, bahwa DPD menjadikan laporan pemriksaan keuangan negara oleh BPK sebagai bahan untuk melaksanakan fungsi pengawasan dan memberikan pertimbangan mengenai RUU APBN yang secara prosedural bermuara kepada DPR, untuk menindaklanjutinya; 
Hubungan ini dapat dikatakan sebagai hubungan perantaraan yang hanya memperpanjang prosedur kerja, maka agar lebih evisien sebaiknya hasil pemeriksaan BPK langsung saja diberikan kepada DPR.

Hubungan DPD dengan lembaga yudikatif, baik itu Mahkamah Agung maupun Mahkamah Konstitusi, boleh dikatakan tidak ada hubungan sama sekali, karena dalam hal menentukan Hakim Agung sepenuhnya menjadi kewenangan DPR dan tidak melibatkan DPD sama sekali, namun demikan dalam hal anggota DPD sebagai anggota MPR yang mempunyai kewenangan merubah UUD, maka ada hubungannya dengan Mahkamah Konstitusi sebagai penjaga konstitusi.

\section{KESIMPULAN}

1. Dewan Perwakilan Daerah (DPD) sebagai lembaga negara yang mewakili daerah di tingkat pusat, mempunyai kedudukan yang sejajar dengan lembaga negara lainnya, namun demikian hanya diberi kewenangan dan fungsi yang sangat terbatas, sehingga tidak dapat mempresentasikan kepentingan daerah di tingkat pusat. Sebagai lembaga perwakilan tidak mempunyai fungsi legislasi, anggaran dan pengawasan seperti yang dimilki oleh DPR. DPD dapat melaksanakan itu tetapi harus lewat DPR.

2. Hubungan Dewan Perwakialan Daearah (DPD) dengan lembaga negara lainnya tidak menggambarkan hubungan yang berkonskwensi ketatanegaraan, karena DPD tidak diberi hak untuk mengambil keputusan politik dan kibijakan nasional, maka dapat dikatakan hanya terbatas sebagai hubungan pembantuan, karena hanya melaksanakan tugas dan fungsi membantu lembaga negara lainnya.

\section{DAFTAR PUSTAKA}

Arif, Sidarta, Refleksi tentang Fundasi dan sifat Keilmuan Ilmu Hukum Sebagai Landasan Hukum Nasional. (disertasi) Pascasarjana UNPAD Bandung, 1996.

Asshiddiqie, Jimly, Format Kelembagaan Negara dan Pergeseran Kekuasaan dalam UUD 1945 FH UII Press, Yogyakarta, 2004.

Asshiddiqie Jimly, Islam dan Kedaulatan Rakyat, Gema Insani Press, Jakarta, 1995.

Asshiddiqie, Jimly, Gagasan Kedaulatan Rakyat dalam Konstitusi dan Pelaksanaannya di Indonesia, PT Ictiar Baru Van Hoeve, Jakarat, 1994.

Budiardjo, Miriam, Masalah Kenegaraan, PT. Garmedia, Jakarta, 1982.

Huda, Ni'matul, Politik Ketatanegaraan Indonesia, Kajian terhadap Dinamika Perubahan UUD 1945, FH UII Press, Yogyakarta, 2003.

Lubis, M Solly, Hukum Tata Negara, Mondar Maju, Bandung 2002.

Malian, Sabirin, Gagasan Perlunya Konstitusi Baru Pengganti UUD 1945, UII Press, Yogyakarta, 2001. 
Manan, Bagir, MPR, DPR dan DPD dan UUD 1945 Baru, FH UII Press, Yogyakarta, 2003.

Nasroen, M, Asal Mula Negara, Aksara Baru, Jakarta, 1986.

Puspa, Yan Pramudya, Kamus Hukum, Aneka Ilmu, Semarang, 1977.

Soekanto, Soerjono. Pengantar penelitian Hukum, Universitas Indonesia, Jakarta, 2005.

Saragih Bintan R. Lembaga Perwakilan dan Pemilihan Umum di Indonesia, Gaya Media Pratama, Jakarta, 1988. 